\title{
The Spirituality Dimensions of Christian Religious Education Teacher
}

\author{
Delipiter Lase L $^{1 凶}$ \\ ${ }^{1}$ STT Banua Niha Keriso Protestan Sundermann Nias \\ piterlase@sttsundermann.ac.id
}

Received: 28 September 2021 | Revised: 31 October 2021 | Accepted: 31 October 2021 | Published online: 31 October 2021 Copyright (C) The Author(s) 2021

\begin{abstract}
Spirituality must be possessed by Christian religious education (CRE) teachers, considering that the teaching he does aims to pave the way for learners to spirituality through the formation of perfect character, morals, and social. Therefore, this article seeks to identify the spiritual values that a CRE teacher should have and how the spiritual values are internalized in his personal life. This article is a conceptual framework based on a theoretical review. To develop concepts relevant to the topic, the author reviews literature from books and scientific journals, research reports, scientific essays, thesis and dissertations, encyclopedias, and other print and electronic sources. Based on a review of various sources, including spirituality according to Christianity, the author explains the essential spiritual values that a CRE teacher must possess. The author groups them into two dimensions, namely the personal dimension and the relational dimension.
\end{abstract}

Keywords: Christian religious education, CRE teacher, personal, relational, spirituality

\section{Introduction}

A Christian religious education teacher is expected to be a good and effective teacher; he also plays a clergyman role. Schools often assigned CRE teachers the burden of being preachers in religious activities in the school environment, handling various social activities in the scope of the school's big family, and becoming a school advisor in decision making. A CRE teacher's expectations are high; he must perform various roles and has a high spirituality that can see in his attitude and behavior. Spirituality is one of the essential aspects that he must possess because educating is not just mechanical work but also facing the challenges of pluralism of values, beliefs, and spirituality. A CRE teacher's spirituality becomes imperative because the teaching he does aims to improve students' spirituality. He should have good spirituality so that they can be role models in their teaching.

The spirituality of someone who teaches the word of God has been emphasized in Titus 2:7-8 "In all things shewing thyself a pattern of good works: in doctrine shewing uncorruptness, gravity, sincerity, sound speech, that cannot be condemned; that he that is of the contrary part may be ashamed, having no evil thing to say of you." Here, Paul advised Titus, who was commissioned on the island of Crete, to be a role model of good deeds according to God's word that he taught. Titus is required to live first according to the word of God that he taught before teaching others. Exemplary is a practical act of the right attitude in life, which Titus must show, and everyone can observe.

Everyone hopes that religious education teachers have high spirituality. However, in some cases, we found that CRE teachers only transfer knowledge to students but do not demonstrate exemplary spirituality through attitudes and behavior. This difference occurs for various reasons; they have not realized that a CRE teacher needs to have good spirituality to display practical personal competence. CRE teachers often see themselves the same as other subject teachers. Not all CRE teachers can interpret the Christian faith, become shepherds for their students, and serve as evangelists. This fact shows that the values of spirituality have not been fully internalized in CRE teachers. 
Several people interpret spirituality in a narrow definition and are limited to religious activities. Interpret spirituality as limited to the actions of those who meditate in lonely and unusual places. There is also a view that people who diligently worship and engage in various religious activities are spiritual; assume that people who have supernatural abilities have a high degree of spirituality. The servants of God, such as priests, religious scholars, monks, must be spiritual people.

According to Rahmiati Tanudjaja, several benchmarks are often used by Christians today to measure one's spirituality. Namely, one is involved in spiritual activities and various social servicesthe appearance of supernatural phenomena throughout his life; a lifestyle that eschews worldly activities. Christian attributes, such as people who always carry the Bible, wear accessories, or always listen to Christian songs, are considered more godly than those who do not wear them. ${ }^{1}$ However, the above measure cannot be an appropriate benchmark because true spirituality does not focus on superficial religious activities and bases itself on moral values and obligations.

As a result of this narrow and limited understanding, the notion of spirituality is shifting and increasingly unclear. Some people are active in religious activities that have bad daily behavior, and vice versa; also, those who are ordinary in following religious activities have good spirituality. Even this closed and limited understanding does not cause deviant behavior, for example, when acts of terrorism by detonating bombs in houses of worship or public places known as jihad are believed to be forms of spirituality; or when the act of stealing money and then distributing it to the needy is considered a spiritual act. Therefore, spirituality must be understood broadly.

Over the last few decades, the term spirituality has entered the common language as an alternative way to describe our search for transcendence. In English, spiritual is a term used to distinguish church life naturally or materialistically. ${ }^{2}$ In the 19th century, spirituality was not a commonly used term, and Spiritualism referred to contact with spirits and other psychic phenomena. This term has

\footnotetext{
${ }^{1}$ Rahmiati Tanudjaja, "Anugerah Demi Anugerah Dalam Spiritualitas Kristen Yang Sejati," Veritas, no. 2 (October) (2002): 171-182.

${ }^{2}$ Ana-María Rizzuto, "Psychoanalytic Considerations about Spiritually Oriented Psychotherapy.," in Spiritually Oriented Psychotherapy. (Washington: American Psychological Association, 2005), 31-50, http://content.apa.org/books/10886-002.
}

several common meanings, ${ }^{3}$ and definitions in scientific literature also vary. These differences reflect that spirituality is a broad term that encompasses various domains of meaning that may differ among various cultural, national, and religious groups. ${ }^{456}$ Today, this term is often used to indicate our relationship's experience and personal side with the transcendent or sacred. ${ }^{789}$ Those who use the term in this way usually contrast with religion, which they narrowly define as religious groups' organizational structure, practices, and beliefs. ${ }^{10}$ On the other hand, theologians and practitioners of religion tend to prefer a less attractive definition of a strict separation between religion and spirituality. ${ }^{11}$ In their eyes, spirituality is the reality of religious life as experienced by adherents of tradition.

"Spirituality is distinguished from all other things-humanism, values, morals, and mental health - by its connection to that which is sacred,

\footnotetext{
${ }^{3}$ Brian J. Zinnbauer et al., "Religion and Spirituality: Unfuzzying the Fuzzy," Journal for the Scientific Study of Religion 36, no. 4 (December 1997): 549, https://www.jstor.org/stable/1387689? origin=crossref.

${ }^{4}$ E. Lewis, "Posture as a Metaphor for Biblical Spirituality," in The Destructive Power of Religion: Violence in Judaism, Christianity and Islam, ed. J. Ellens, vol. 4 (Westport, CT: Praeger, 2004), 143-174.

${ }^{5}$ Eugene C. Roehlkepartain et al., "Spiritual Development in Childhood and Adolescence: Moving to the Scientific Mainstream," in The Handbook of Spiritual Development in Childhood and Adolescence, ed. E. Roehlkepartain and P. King (2455 Teller Road, Thousand Oaks California 91320 United States: SAGE Publications, Inc., 2006), 1-15,

http://sk.sagepub.com/reference/hdbk_childspiritdev/n1.xml.

${ }^{6}$ Masami Takahashi and Satoshi Ide, "Implicit Theories of Spirituality across Three Generations: A Cross-Cultural Comparison in the U.S. and Japan," Journal of Religious Gerontology (2003).

${ }^{7}$ James M. Nelson, Psychology, Religion, and Spirituality, ed. James M. Nelson (New York, NY: Springer New York, 2009), http://link.springer.com/10.1007/978-0-38787573-6.

${ }^{8}$ Robert A. Emmons and Cheryl A. Crumpler, "Religion and Spirituality? The Roles of Sanctification and the Concept of God," The International Journal for the Psychology of Religion 9, no. 1 (January 16, 1999): 17-24, http://www.tandfonline.com/doi/abs/10.1207/s15327582ijpr090 1_3.

${ }^{9}$ Peter C. Hill et al., "Conceptualizing Religion and Spirituality: Points of Commonality, Points of Departure," Journal for the Theory of Social Behaviour 30, no. 1 (March 25, 2000): 51-77,

https://onlinelibrary.wiley.com/doi/abs/10.1111/14685914.00119.

${ }^{10}$ Brian J. Zinnbauer, Kenneth I. Pargament, and Allie B. Scott, "The Emerging Meanings of Religiousness and Spirituality: Problems and Prospects," Journal of Personality (1999).

${ }^{11}$ Nelson, Psychology, Religion, and Spirituality.
} 
the transcendent. The transcendent is that which is outside of the self, and yet also within the self-and in Western traditions is called God, Allah, HaShem, or a Higher Power, and in Eastern traditions may be called Brahman, manifestations of Brahman, Buddha, Dao, or ultimate truth/reality. Spirituality is intimately connected to the supernatural, mystical, and organized religion, although it extends beyond organized religion (and begins before it). Spirituality includes both a search for the transcendent and the discovery of the transcendent and so involves traveling along the path that leads from no consideration to questioning to either staunch nonbelief or belief, and if belief, then ultimately to devotion finally, surrender. Thus, our definition of spirituality is very similar to religion, and there is overlap."12

In Spirituality and History, Philip Sheldrake defines spirituality as "the conscious human response to God that is both personal and ecclesial."13 Dharmaputra understands that spirituality is the spirit, soul, and passion. Spirituality ranks first on a scale of priorities. Like a church with all kinds and everything: church buildings, priests, activities, finance, many activities, but without spirituality that is spirit, soul, enthusiasm, and passion, all of that will turn into just a church routine. ${ }^{14}$ Meanwhile, Eliade stated that Christian spirituality is a Christian way of life, worshiping and developing a relationship with Christ. ${ }^{15}$ It means that Christian spirituality results from the relationship between humans and Christ, which is then manifested in Christians' daily way of life who emulate Christ. A good relationship between humans and Christ will enable the person to behave well in his life, love his fellow man, and forgive.

Christian spirituality concerns the quest for a fulfilled and authentic Christian existence, involving bringing together the fundamental ideas of Christianity and the whole experience of living based on and within the Christian faith scope. ${ }^{16}$ McGrath's view implies that Christian spirituality

\footnotetext{
${ }^{12}$ Harold Koenig, Dana King, and Verna B. Carson, Handbook of Religion and Health, 2nd ed. (New York, NY, USA: Oxford University Press, 2012).

${ }^{13}$ Philip Sheldrake, "Spirituality: A Brief History," in Statewide Agricultural Land Use Baseline 2015, 2nd ed. (Somerset, New Jersy: John Wiley and Sons, 2013), 23-46.

${ }^{14}$ Eka Darmaputera, Spiritualitas Siap Juang (Jakarta: BPK Gunung Mulia, 2011).

${ }^{15}$ Mircea Eliade, The Encyclopedia of Religion, 3rd ed. (New York: Macmillan Publishing, 1986).

${ }^{16}$ Alister E. McGrath, Christian Spirituality: An Introduction (Oxford: Blackwell Published, 1999).
}

can be understood as a way taken by Christians, both individually and in groups, to deepen their experience with God or practice God's presence. So that Christian spirituality is manifested in prayers to God, personal reflection, praise, and worship to God through singing, meditation, and good living behavior as the fruits of the spirit in the lives of Christians.

Meanwhile, Victor Tanja stated that Christian spirituality is an attitude of life that results in love, joy, peace, prosperity, patience, kindness, gentleness, and self-control. Christian spirituality is an expression of the attitude of life that always works because with that work, our lives bring others to life and bring good to all people who are God's fellow creatures. ${ }^{17}$ It shows that Christian spirituality is the attitude and way of life of Christians who bring good to others around them.

Within the academic sphere, spirituality (spiritual quotient) is discussed scientifically by Danah Zohar (a psychologist) and Ian Marshall (a physicist) in a book called SQ: Spiritual Intelligence - The Ultimate Intelligence (2000). The book discusses spiritual intelligence as a determining factor for the effectiveness of intellectual intelligence and emotional intelligence. The Zohar defines spiritual intelligence as intelligence to face and solve problems of meaning and value, namely intelligence to place our behavior and life in the context of a broader and richer meaning, intelligence to judge that someone's actions or way of life are more meaningful than others. The spiritual quotient is the foundation needed to function intelligence quotient and emotional quotient effectively. Even the spiritual quotient is our highest intelligence. ${ }^{18}$

Here Zohar links SQ with intelligence quotient and emotional quotient. A high intelligence quotient enables someone to think, and EQ enables someone to decide to be right following the conditions they face. Hence, SQ enables someone to decide whether he wants to be in a situation like that. IQ and emotional quotient work within the boundaries of the situation, while SQ enables someone to change or improve the situation they face.

Margot Cairnes, an education expert, in Tanudjaja provides a definition that confirms

\footnotetext{
${ }^{17}$ Victor Tanja, Spiritualitas, Pluralitas, Dan Pembangunan Di Indonesia (BPK Gunung Mulia, 1996).

${ }^{18}$ Zohar \& Marshall and Jenny King, "SQ: Spiritual Intelligence: The Ultimate Intelligence," Psychology and Psychotherapy 75, no. January (2002): 116-117.
} 
Zohar's statement by saying that the spiritual quotient is a person's ability to ask questions, think creatively, change rules, work effectively in situations that change beyond existing boundaries, penetrate obstacles. Existing obstacles and making innovation. ${ }^{19}$ Cairnes's opinion shows that spiritual intelligence is the ability of a person to change or improve a particular situation creatively and innovatively to be better.

It appears that people who have a spiritual quotient can understand others' feelings, can read explicitly and implicitly, grasp the verbal and nonverbal language, and treat others well as he also wants to be treated well by others. His insights will lead him to behave and act according to the needs and demands of his environment. In other words, spiritual intelligence can help someone to respond to the demands of their environment appropriately. Also, it shows explicitly that the spiritual quotient has a relationship with a person's belief in his Lord or is inseparable from the religion that is believed.

Furthermore, in Christianity, spirituality begins when a person believes and accepts Jesus as his personal Savior. That person is given power by God, as stated in the word of the Lord, "But as many as received him, to them gave he power to become the sons of God, even to them that believe on his name; which were born, not of blood, nor the will of the flesh, nor the will of man, but God" (John 1: 12-13). This verse explains that God gives every believer the power to become children of God who behaves and lives according to God's will. That attitude and way of life that is following God's will is called Christian spirituality. From the experts' view above, the author believes that spirituality is a state of spiritual nature regarding the actual relationship and obedience of someone who believes in God. The actual relationship and obedience flow the spirit and encouragement in the person to behave, speak, and think according to God's teachings/commands, he believes.

\section{Method}

This article is a conceptual framework based on a theoretical review. To develop concepts relevant to the topic, the author conducted a literature study obtained from books and scientific journals, research reports, scientific essays, theses and dissertations, encyclopedias, and other printed and electronic sources to develop concepts relevant to the topic. Furthermore, to get precise characteristics

\footnotetext{
${ }^{19}$ Tanudjaja, “Anugerah Demi Anugerah Dalam Spiritualitas Kristen Yang Sejati."
}

of the discourse in the form of theories and concepts being studied, the authors use the content analysis method, a research technique to make inferences that can be replicated and valid data by paying attention to the context. ${ }^{2021}$

\section{Finding and Discussion}

\section{The Dimension of Spirituality in CRE Teacher Personality Competencies}

Thomas Groome defines Christian Education as "a political activity with pilgrims in time that deliberately and intentionally attends with them to the activity of God in our present, to the Story of the Christian faith community, and the Vision of God's Kingdom, the seeds of which are already among us." 22 As the process whereby Christian learning takes place. It often involves "teaching, which enables practicing Christians to adopt and deepen their Christian beliefs, values, and dispositions to experience and act in a Christian way. It depends to a greater extent on how this process is adopted and practiced in different churches."23 George Albert Coe in Christopher Byaruhanga defines Christian religious education as "the systematic, critical examination and reconstruction of relations between persons, guided by Jesus' assumption that persons are of infinite worth, and by the hypothesis of the existence of God, the Great Valuer of persons." 24

In line with it, the authors argue that Christian religious education teaches people to know who Jesus Christ is and have faith in Jesus Christ indeed. Thus, CRE teaches the knowledge and the views, beliefs, dogmas, or theology that a person has about Jesus Christ. Religious education should be given a truth under the corridor of God's word, which is the

\footnotetext{
${ }^{20}$ Klaus Krippendorff, Content Analysis: An Introduction to Its Methodology (Second Edition), SAGE Publications, 2004.

${ }^{21}$ Rachmat Kriyantono, Teknik Praktis Riset Komunikasi, 6th ed. (Jakarta: Kencana Prenada Media Grup, 2012).

${ }^{22}$ Thomas H. Groome, Christian Religous Education: Sharing Our Story and Vision (San Francisco: Jossey-Bass Publishers, 1980).

${ }^{23}$ UKEssays, "What Is Christian Religious Education?," last modified 2018, accessed December 31, 2019, https://www.ukessays.com/essays/religion/the-definition-ofchristian-religious-education-theology-religionessay.php?vref=1.

${ }^{24}$ Christopher Byaruhanga, Essential Approaches to Christian Religious Education, Learning and Teaching in Uganda (Geneva: Globethics.net, 2018), https://www.globethics.net/documents/4289936/15469226/GE_ Praxis_9_isbn9782889312344.pdf/74888ec4-26a5-4bac-9fc0$068 \mathrm{c} 23755 \mathrm{eb} 6$.
} 
principle and fundamental. CRE is an essential tool in preparing someone to face the future. That is why the quality of teachers must constantly be improved. The increase is not only an increase in theory, but the CRE teacher must also experience an increase in spirituality, in the sense that he grows and lives according to what he teaches to his students.

According to Sidjabat, at least six theological foundations are essential elements in Christian religious education activities, namely (1) knowledge of God; (2) a view of the position and function of the Bible; (3) an introduction to Jesus Christ; (4) the Holy Spirit and His people; (5) humans, position and vocation; and (6) maturity ${ }^{25}$.

Based on the description above, Christian religious education's nature can be understood more broadly than just teaching, nurturing, socializing, and enculturation. As an educational concept, Christian religious education has assumptions about the efforts made consciously, systematically, and continuously. However, education is devoted to the religious dimension of human life. Furthermore, the addition of the word 'Christian' to the term confirms that education in the religious dimension of human life is carried out from the perspective of Christianity, with the context and content of Christianity.

Who is the CRE teacher? The Republic of Indonesia Law No. 14/2005 concerning teachers and lecturers explains that teachers are professional educators who educate, teach, guide, direct, train, assess, and evaluate students in early childhood education in the paths of formal education, primary and secondary education. Thus, the teacher has the expertise, skills, and skills to professionally perform their duties at formal education, starting from the lowest level to secondary education.

It shows a teacher is a person who has more knowledge, so he is more intelligent than his students. The teacher has the skills to give instructions in the teaching-learning process and educate. The teacher teaches through his mouth, through the expression on his face, through the movement of his limbs, through sign language either consciously or unconsciously, through his attitude and nature: polite, friendly, caring, responsive, assertive, conscientious, neat, clean, brave, disciplined, intelligent, careful, dexterous, skilled, and so on. Teachers are imitated and

${ }^{25}$ B. S Sidjabat, Mengajar Secara Profesional : Mewujudkan Visi Guru Profesional (Yayasan Kalam Kudus, 2009). encouraged by students. Therefore the teacher should ideally be an example for his students. The Apostle Paul wrote to Timothy - and this was also relevant to teachers, who set an example in terms of words, behavior, love, faithfulness, and exemplary in the sanctity of life, which meant that the teacher had to keep his faith, holiness, and abstain from various despicable acts. Therefore, CRE teachers are professional educators who have assignments in Christian religious education, not entirely different from the general teachers, except for their task fields. However, as a CRE teacher, there are essential differences in spirituality, faith, love, and preaching. To reinforce this statement, Ionel Ene and Iuliana Barna presented the specificity of intervention for the religious teacher as follows ${ }^{26}$.

"First, qualification - theological seminary, B.A. in theology, teachers' training certificate; general and specific competencies; professional experience. Second, methods - not limited to formal teaching - promote indirect influencing methods of stimulating faith and sensitivity. Third, the teaching objective is mental knowledge, spiritual knowledge, faith development, and sensitivity. Fourth, learning contents - praying and studying the Bible is central to teaching religion; the class will not be reduced to teaching various information and facts. Fifth, curriculum - the teacher must use the same curriculum and the same materials for all the children in the class, but he must also be able to adapt to specific contexts and needs (specific needs of the students as an individual and social requirements, without deflecting from the ethical norms). Sixth, creativity - the teacher gives the student the chance to discover new things, ask questions, look for answers, and get involved in various activities. Seventh, motivation - teaching religion is a profession chosen with both sensible and affective reasons, which is why the desire to open the students a path to spirituality through the formation of a faultless moral and social character is of the essence. Eighth, disciplinary methods should be applied with love as a prerequisite of the teacher-student relationship. They must be used to instruct children in what moral, religious, and social behavior is concerned. Ninth, resources - the religion teacher does not use approved materials exclusively, and he must also create and diversify his resources. Tenth, evaluation - the children should regard evaluation to analyze their activity as

\footnotetext{
${ }^{26}$ Ionel Ene and Iuliana Barna, "Religious Education and Teachers' Role in Students' Formation towards Social Integration," Procedia - Social and Behavioral Sciences 180 (May 2015): 30-35.
} 
a stage towards self-assessment and not as a constraint. Eleventh, control - the teacher must permanently control a class of 20 to 30 students; he must promote a communion of love and respect between the students and the teacher-student relationship. Lastly, time - time spent with the children is not limited to class activities. The children participate in the religious service held at the church or various religious, social, philanthropic events in the community's life. These are auspicious moments that valorize the children's religious education."

Furthermore, according to Homrighausen, CRE teacher spirituality consists of three subcomponents of competence, namely: "having the power of spirituality that awakens teacher professionalism, has a calling spirit and has a mastery of God's word as a source of teaching material." 27

In line with the opinion above and based on the literature review of spirituality, the author argues that the values of Christian spirituality in the CRE teacher's personality can be described in two parts, namely the personal and relational dimensions. Personal dimensions relate to the individual's person, while the relational dimension relates to the relationship between individuals.

Table 1 The spiritual values in the personal and relational dimension

\begin{tabular}{|c|c|}
\hline Dimension & Spiritual Values \\
\hline $\begin{array}{l}\text { Personal } \\
\text { dimension }\end{array}$ & $\begin{array}{l}\text { - A good relationship with God } \\
\text { - Trust and accept Jesus as his } \\
\text { Saviour } \\
\text { - Led by the Spirit } \\
\text { - Have a life centered on the } \\
\text { Triune God } \\
\text { - Have a life centered on the } \\
\text { Triune God and adhere to the } \\
\text { teachings of the Bible } \\
\text { - Believe in the God he believes in } \\
\text { - Maintaining the sanctity and } \\
\text { - } \text { holiness of life } \\
\text { - Aurposefully life } \\
\text { - } \text { creatures created by God } \\
\text { - Think positively }\end{array}$ \\
\hline $\begin{array}{l}\text { Relational } \\
\text { dimension }\end{array}$ & $\begin{array}{l}\text { - Patient } \\
\text { - } \text { Flexible and adaptive to the } \\
\text { environment } \\
\text { - Stabel emotions }\end{array}$ \\
\hline
\end{tabular}

${ }^{27}$ E.G. Homrighausen and I.H. Enklaar, Pendidikan Agama Kristen (Jakarta: BPK Gunung Mulia, 2005), 180-181.
- Solid and resilient in the face of suffering and pain independent

- Loyal

- Responsible

- Joyful

- A good relationship with God. A good CRE teacher must be a role model for students in establishing a relationship with God through singing and prayer activities (Acts 2: 43-47) and in terms of fellowship and worship (Heb. 10:25). Perform spiritual practices such as meditation, devotion (Matt. 14: 13a; Mark 1:35), and recognize that the task as an educator is the task of God's call in his life.

- Trust and accept Jesus as his Savior. It can be seen when CRE teachers dared to acknowledge Jesus as their Savior and encourage their students to accept and acknowledge Jesus as their personal Lord and Savior; make Jesus an example in his life and teaching.

- Led by spirit. Have spirit, soul, enthusiasm in carrying out teaching tasks; wise in dealing with various personal and related problems, as a teacher (Isaiah 33:6; Ephesians. 1:17); diligently carrying out duties as a teacher confident.

- Have a life centered on the Triune God and adhere to the teachings of the Bible. He is making the Triune God the center of teaching, the Bible as the basis for teaching (2 Tim. 3:16), and interpreting God's word according to hermeneutic principles.

- Believe in the God he believes in. Dare to testify about faith and encourage students to bear witness to their faith; Encourage students to entrust their lives and fight into God's hands and believe that God can complete their struggle.

- Maintaining the sanctity and holiness of life. Stay away from things that are contrary to the teachings of Christ (Romans 13:13), and uphold the instructions and rules of the church.

- Purposefully life. Have a vision of life, show the right direction for students' lives through advice, reprimand, criticism, and guidance (1 Pet. 2:9; Mk 12:29-30) as well as being a motivator for students' personal lives

- A good relationship with fellow creatures of God. Have a good relationship with every member of the family (1 Tim. 3:1-7) and a good working relationship with others. Preserve the universe by being an example for students and co-workers through concrete actions (Gen. $1: 28)$. 
- Think positively. Not prejudiced against students and colleagues, able to take valuable lessons from a failure, and optimistic in life

- Be patient. Able to deal with various student behaviors (Col. 3: 12-13)

- Flexible and adaptive to the environment. Able to manage class well, be a friend to the students, respect colleagues, be loyal to the leader, and learn strategies and methods implemented creatively and varied.

- Stable emotions. Steadfast and persistent, do not give up quickly, and self-introspection; optimistic, calm, tolerant, and logical.

- Solid and resilient in the face of suffering and pain. It is not easy to give up, complain, or grumble, develop themselves by expanding literacy through training, seminars, or workshops, reading various sources related to the work field, improving professional skills for teaching in technology literation, and working hard.

- Loyal. Complete the task to completion, not leave the assignment, and be ready to be placed or assigned anywhere.

- Responsible. Taking risks, not blaming others, and getting the job done on time.

- Joyful. Pleasant (1 Sam. 2:26); beaming or not glum (Proverbs 15:13), and able to convey words of comfort to students who experience sadness (2 Cor. 2: 7).

\section{Internalization of Spiritual Values in CRE Teachers}

Values that have been intact in someone will form a mindset in seeing the meaning of the reality of experience. These values can be from various aspects of religion, culture, social norms, and others: the meaning colors humans' meaning and attitude towards themselves, the environment, and reality. Internalization is a process that lasts throughout an individual's life, from the time he was born until the end of his life.

The development of student spirituality within the school's scope should occur through an internalization process because schools are a social system. "School, as a social system, describes schools as institutions and suggests a model of analysis that addresses the complex and often contradictory purposes of schooling." ${ }^{28}$ The situation in schools is not much different from the situation in society. Schools have characteristics

\footnotetext{
${ }^{28}$ Peter W. Cookson, "School as a Social System," in International Encyclopedia of the Social \& Behavioral Sciences: Second Edition, 2015.
}

similar to those within the social system. The social institution called the school is a small society that has a culture. School culture and interaction between individuals within it will give birth to a social system.

Therefore, education takes place through internalizing values that are manifested through interactions between everyone in it. Through interaction, one will imitate the views, lifestyle, and spirituality of other colleagues. Of course, this is where leaders are always required to make themselves transparent or observable and open in front of the people they serve.

The teacher's role as an example and role model when interacting with fellow teachers and students is essential. Students will observe him but at the same time become observers of the process of interaction of people in the group. He becomes a facilitator who motivates or enables meaningful communication to occur correctly. $\mathrm{He}$ is a leader and a member of his group who is needed and needs others. Correspondingly, he is required to show the value and attitude of life as a servant. As a form of spirituality to God, as well as being the center of his teaching. Thus, a teacher can be a living curriculum because his whole life becomes a learning source for his students.

It is in line with the Ono Niha (Nias) proverb that says "mangumä̈ daromali, mango'ou mbuabua," which means that theory can teach. However, actions encourage others who see it to take part in doing it. Therefore, if the CRE teacher wants his students to have good spirituality, they must teach them words and actions.

\section{Conclusion}

CRE teachers are professional educators who have assignments in CRE subjects. What distinguishes it from the teacher in general lies in the dimensions of spirituality, affection, and preaching. Besides being professional education, a teacher of Christian religious education has a unique role as an interpreter of the Christian faith, a shepherd for his students, and serving as an evangelist responsible for each of his students' handover of Jesus Christ.

Learning outcomes held by CRE teachers in the form of changes in each student in general and human literacy, in particular, will only be achieved maximally if the CRE teacher has a set of competencies, including personality competencies. To strengthen this personality competency, a CRE teacher must have good spirituality. The values of spirituality in personality competence will appear in 
the personal and relational dimensions in implementing tasks and their role as CRE teachers.

A teacher's real life is like an open book that everyone can read, including students. This aspect is interrelated with the student's assessment of the CRE teacher's personality, meaning that students will follow the example shown by him in general. Problems will arise if the CRE teacher cannot show an example. As a result, student assessments of teachers become less valuable and can cause a decrease in students' interest or motivation to grow in faith in God.

"Do not try to fix the students; fix ourselves first. A good teacher makes the poor student good and the good student superior. When our students fail, we, as teachers too, have failed." 29 This sentence state that a good teacher must first be better than his students. If he expects his students to be fair, he must be far better than them, and if he wants his students who are already promising to be superior, then the teacher must be superior to them. When a student fails, it means that the teacher has failed to become a teacher.

\section{References}

Byaruhanga, Christopher. Essential Approaches to Christian Religious Education, Learning and Teaching in Uganda. Geneva: Globethics.net, 2018.

https://www.globethics.net/documents/4289936/15 469226/GE_Praxis_9_isbn9782889312344.pdf/74 888ec4-26a5-4bac-9fc0-068c23755eb6.

Collins, Marva. "The Outstanding Educator." Bleacherreport.Com. Last modified 2008. Accessed May 13, 2019. https://bleacherreport.com/articles/53191-marvacollins-the-outstanding-educator.

Cookson, Peter W. "School as a Social System." In International Encyclopedia of the Social \& Behavioral Sciences: Second Edition, 2015.

Darmaputera, Eka. Spiritualitas Siap Juang. Jakarta: BPK Gunung Mulia, 2011.

Eliade, Mircea. The Encyclopedia of Religion. 3rd ed. New York: Macmillan Publishing, 1986.

Emmons, Robert A., and Cheryl A. Crumpler. "Religion and Spirituality? The Roles of Sanctification and the Concept of God." The International Journal for the Psychology of Religion 9, no. 1 (January 16, 1999): 17-24.

http://www.tandfonline.com/doi/abs/10.1207/s153 27582ijpr0901_3.

Ene, Ionel, and Iuliana Barna. "Religious Education and

${ }^{29}$ Marva Collins, "The Outstanding Educator,"

Bleacherreport.Com, last modified 2008, accessed May 13, 2019, https://bleacherreport.com/articles/53191-marva-collinsthe-outstanding-educator.
Teachers' Role in Students' Formation towards Social Integration." Procedia - Social and Behavioral Sciences 180 (May 2015): 30-35.

Groome, Thomas H. Christian Religious Education: Sharing Our Story and Vision. San Francisco: Jossey-Bass Publishers, 1980.

Hill, Peter C., Kenneth II. Pargament, Ralph W. Hood, Michael E. McCullough, Jr., James P. Swyers, David B. Larson, Brian J. Zinnbauer, et al. "Conceptualizing Religion and Spirituality: Points of Commonality, Points of Departure." Journal for the Theory of Social Behaviour 30, no. 1 (March 25, 2000): 51-77.

https://onlinelibrary.wiley.com/doi/abs/10.1111/14 68-5914.00119.

Homrighausen, E.G., and I.H. Enklaar. Pendidikan Agama Kristen. Jakarta: BPK Gunung Mulia, 2005.

Koenig, Harold, Dana King, and Verna B. Carson. Handbook of Religion and Health. 2nd ed. New York, NY, USA: Oxford University Press, 2012.

Krippendorff, Klaus. Content Analysis: An Introduction to Its Methodology (Second Edition). SAGE Publications, 2004.

Kriyantono, Rachmat. Teknik Praktis Riset Komunikasi. 6th ed. Jakarta: Kencana Prenada Media Grup, 2012.

Lewis, E. "Posture as a Metaphor for Biblical Spirituality." In The Destructive Power of Religion: Violence in Judaism, Christianity and Islam, edited by J. Ellens, 4:143-174. Westport, CT: Praeger, 2004.

McGrath, Alister E. Christian Spirituality: An Introduction. Oxford: Blackwell Published, 1999.

Nelson, James M. Psychology, Religion, and Spirituality. Edited by James M. Nelson. New York, NY: Springer New York, 2009. http://link.springer.com/10.1007/978-0-387-875736.

Rizzuto, Ana-María. "Psychoanalytic Considerations about Spiritually Oriented Psychotherapy." In Spiritually Oriented Psychotherapy., 31-50. Washington: American Psychological Association, 2005. http://content.apa.org/books/10886-002.

Roehlkepartain, Eugene C., Peter L. Benson, Pamela Ebstyne King, and Linda M. Wagener. "Spiritual Development in Childhood and Adolescence: Moving to the Scientific Mainstream." In The Handbook of Spiritual Development in Childhood and Adolescence, edited by E. Roehlkepartain and P. King, 1-15. 2455 Teller Road, Thousand Oaks California 91320 United States: SAGE Publications, Inc., 2006. http://sk.sagepub.com/reference/hdbk_childspiritde $\mathrm{v} / \mathrm{n} 1 . \mathrm{xml}$.

Sheldrake, Philip. "Spirituality: A Brief History." In Statewide Agricultural Land Use Baseline 2015, 23-46. 2nd ed. Somerset, New Jersey: John Wiley and Sons, 2013.

Sidjabat, B. S. Mengajar Secara Profesional : 
Mewujudkan Visi Guru Profesional. Yayasan Kalam Kudus, 2009.

Takahashi, Masami, and Satoshi Ide. "Implicit Theories of Spirituality across Three Generations: A CrossCultural Comparison in the U.S. and Japan." Journal of Religious Gerontology (2003).

Tanja, Victor. Spiritualitas, Pluralitas, Dan Pembangunan Di Indonesia. BPK Gunung Mulia, 1996.

Tanudjaja, Rahmiati. “Anugerah Demi Anugerah Dalam Spiritualitas Kristen Yang Sejati." Veritas, no. 2 (October) (2002): 171-182.

UKEssays. "What Is Christian Religious Education?" Last modified 2018. Accessed December 31, 2019. https://www.ukessays.com/essays/religion/thedefinition-of-christian-religious-educationtheology-religion-essay.php?vref=1.

Zinnbauer, Brian J., Kenneth I. Pargament, Brenda Cole, Mark S. Rye, Eric M. Butter, Timothy G. Belavich, Kathleen M. Hipp, Allie B. Scott, and Jill L.

Kadar. "Religion and Spirituality: Unfuzzying the Fuzzy." Journal for the Scientific Study of Religion 36, no. 4 (December 1997): 549.

https://www.jstor.org/stable/1387689?origin=cross ref.

Zinnbauer, Brian J., Kenneth I. Pargament, and Allie B. Scott. "The Emerging Meanings of Religiousness and Spirituality: Problems and Prospects." Journal of Personality (1999).

Zohar \& Marshall, and Jenny King. "SQ: Spiritual Intelligence: The Ultimate Intelligence." Psychology and Psychotherapy 75, no. January (2002): 116-117. 